\title{
Sporcu Algılarına Göre Halter Antrenörlerinin Etik Liderlik Davranışlarının İncelenmesi*
}

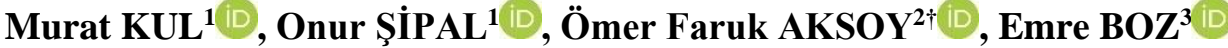 \\ ${ }^{1}$ Bayburt Universitesi, BESYO, Bayburt. \\ ${ }^{2}$ Bayburt Universitesi, Lisansüstü Eğitim Enstitüsü, Bayburt. \\ ${ }^{3}$ Atatürk Üniversitesi, Kış Sporları ve Spor Bilimleri Enstitüsü, Erzurum.
}

Orijinal Makale

Gönderi Tarihi: 21.10.2020
Kabul Tarihi: 02.12.2020
DOI: $10.25307 /$ jssr.814175

Online Yayın Tarihi: 31.12 .2020

\section{$\ddot{\mathbf{O} z}$}

$\mathrm{Bu}$ araştırmanın temel amacı halter antrenörlerinin etik liderlik davranışlarının sporcular tarafından değerlendirilmesi ve bu verilerin demografik değişkenler açısından incelenmesidir. Araştırma grubunu 266 katılımcı oluşturmaktadır. Veri toplama amacı ile Yılmaz'ın (2005) geliştirdiği "Etik Liderlik Ölçeği” kullanılmıştır. Verilerin analizinde, yüzde ve frekans dağılımlarının yanı sıra Pearson Momentler Çarpımı Korelasyon Analizi, One-Way ANOVA ve t-Testi uygulanmıştır. Araştırma sonuçlarına göre cinsiyet, eğitim durumu ve milli sporcu olma değişkenlerinde anlamlı farklılı̆ga rastlanmazken (p>0,05), yaş değişkeni ile "İklimsel Etik" ve "Karar Vermede Etik" alt boyutları düşük düzeyli negatif yönde ilişki olduğu tespit edilmiştir. Antrenörlük kademesi değişkenine bağl1 Etik Liderlik Ölçeğinin tüm alt boyutlarında anlamlı farklılığa ulaşılırken, görev yılı değişkenine bağlı yalnızca "Karar Vermede Etik" alt boyutunda anlamlı farklılığa ulaşılmıştır $(p<0,05)$. Elde edilen bulgular 1şı̆̆ı̆ıda, liderlik özellikleri bakımından halter antrenörlerinin; yaşları arttıkça iklimsel ve karar vermede etik değerleri daha az sergiledikleri, antrenörlük kademeleri arttıkça iletişimsel, iklimsel, davranışsal ve karar vermede etikten uzaklaştıkları, görev süreleri arttıkça mesleki deformasyon kaynaklı, karar vermede etik kurallara daha az yer verdikleri düşünülmektedir.

Anahtar kelimeler: Etik liderlik, Etik, Halter, Antrenör.

\section{Weightlifting Trainers' Ethical Leadership Behaviors According to Athlete Perceptions}

\begin{abstract}
The main purpose of this study is to evaluate the ethical leadership behaviors of weightlifting trainers by athletes and to examine these data in terms of demographic variables. The research group consists of 266 participants. "Ethical Leadership Scale" developed by Yilmaz (2005) was used for data collection. In the analysis of the data, Pearson Product Moment Correlation Analysis, One-Way ANOVA and t-Test were used as well as percentage and frequency distributions. According to the results of the study, no significant difference was found in the variables of gender, educational status, and being a national athlete ( $p>0.05$ ), while a low-level negative relationship was found between the age variable and the subdimensions of "Climatic Ethics" and "Ethics in Decision Making". While a significant difference was reached in all subdimensions of the Ethical Leadership Scale depending on the coaching level variable, a significant difference was reached only in the "Ethics in Decision Making" sub-dimension depending on the duty year variable $(\mathrm{p}<0.05)$.In the light of the findings obtained, in terms of leadership features, weightlifting trainers; It is thought that as their age increases, they exhibit less climatic and ethical values in decision-making, as their coaching levels increase, they move away from ethics in communicative, climatic, behavioral and decision-making, and as their term of office increases, they give less place to ethical rules in decision-making due to professional deformation.
\end{abstract}

Keywords: Ethical leadership, Ethic, Weightlifting, Coach.

*Bu çalışma 16 Mayıs 2020 tarihinde Bilimsel Araştırma ve Proje Geliştirme Derneği Sosyal Bilimler ve Eğitim Bilimleri Öğrenci Kongresi'nde sözel bildiri olarak sunulmuştur.

† Sorumlu yazar: Ömer Faruk AKSOY, E-posta: 06aksoy14@gmail.com 


\section{GíRiş}

İnsanlık tarihi kadar eski olan yönetim ve liderlik olgusu, bireyleri hedefleri doğrultusunda yönetme amacıyla kullanılan en eski sanat olarak kabul edilir (Taylor, 2018). İnsanoğlu, ihtiyaçlarını karşılamak ve hayatına yönelik tehlike arz edebilecek unsurları yönetebilmek gibi nedenlerle topluluklar halinde yaşamını sürdürmeye başladığı günden itibaren ortak kararlarda buluşma ve uygulama konusunda, menfaatlerini ifade etmede, sorumluluklarını karşılamada ve çatışmalarının çözüm üretme sürecinde liderlere ihtiyaç duymuştur (Argüden, 2016).

Liderlik kavramını farklı kişiler ve sektörler kendi bilgi düzeyleri, kültür ve bakış açılarına göre farklı anlamlar yükleyerek tanımlamaktadırlar (Güçlü ve Koşar, 2018). Bu farklılaşmaya karşın liderlik kavramının temelini, bir grup insanı ya da bir kuruluşa bağlı grubu etkilemek ve harekete geçirmek amacıyla motive edebilme ifadeleri oluşturmaktadır (Meier ve Henderson, 2016). Etik liderlik ise liderin çevresini algılaması ve kendi değerleri içerisinde yer vermesi olarak tanımlanabilir. İnsan ilişkilerinin ön planda olduğu etik liderlikte, liderin algılanan tavır ve tutumların etik olması yeterli görülmeyip, etik liderlik unsurlarından otorite, amaç, güven, bilgi ve beceriye sahip olması, kavraması ve geliştirmesi beklenmektedir (Yeşilyurt, 2007). Bir liderin, etken rol oynadığı ve önem arz ettiği alanlardan birisi de spor alanıdır. Etik kavramının spor camiasındaki önemli konumundan dolayı, antrenörler görev üstlendikleri tüm süreçlerde karşı karşıya kaldıkları problemlerin çözümünde etik kurallardan faydalanabilirler.

Bir takımın lideri olan antrenör, popüler varsayımlara göre belirli bir alanda uzmandır. Ayrıca tüm oyuncuların potansiyelini geliştirmek ve en iyi sonuçları elde etmek hakkında bilgi ve deneyimini, takım üyelerine rehberlik etmek, onları motive etmek ve etik ilkelere uygun olarak sporcularını yönlendirmek için kullanmalıdır (Gulak Lipka, 2016). Antrenörün, doğal olarak üstlenmiş olduğu temel görevlerinden biri, takımı ile iletişim ve etkileşim içinde olarak, takımına belirlenen hedefleri benimsetmek ve takımı bu hedeflere doğru ilerlemeye ikna etmektir (Meier ve Henderson, 2016). Bir başka ifadeyle; hedeflerine ulaşmaya çalışan bir takımın, bu hedefleri ortaya çıkarmak ve neticelendirmek için liderin sahip olduğu özniteliklerine ve grubu yönetme sorumluluğuna ihtiyacı vardır. Çünkü sporcuların tüm yükü liderin omuzlarındadır (Elahe, Dehnavi, Mansouri ve Nami, 2013; Sunay, 2016).

ICF (Uluslararası Antrenör Federasyonu), bir eğitimci ve lider olarak antrenörün sorumluluklarını yerine getirirken uyması gereken bir takım etik ilkelerin varlığını vurgulamıştır (Uluslararası Antrenör Federasyonu, 2003). Bu bağlamda bir antrenörün sergilenmesi gereken liderlik davranış türlerinden biri de etik liderlik davranışıdır. Etik liderler, kurum/kuruluş içerisindeki her türden yanlış işleyişe tepki göstererek, etik davranışlar sergileyen ve yanlış işleyişin sürdürülmesini engellemek için çaba sarf eden kişilerdir. Etik liderlik davranışlarında yer alan temel amaç, her yönetimsel karar aşamasında yer alması gereken etik boyutların netleştirilmesi ve örgüt içerisinde karar verilme sürecinin yönlendirilmesinde etik ilkeleri oluşturmaktır (Yaman, 2010).

İlgili literatüre dayanarak bir antrenörden etik ilkelere dayanan liderlik beklenmektedir. $\mathrm{Bu}$ liderlik tutumunun ise sporculara ne denli etki ettiğini ve sporcuların görüşlerini belirlemek önem arz etmektedir. Bu bağlamda araştırmanın temel amacı, halter antrenörlerinin etik liderlik davranışlarının demografik değişkenlere göre sporcu algıları doğrultusunda incelenmesidir. 


\section{METOT}

$\mathrm{Bu}$ bölümde, araştırmada kullanılan model, araştırma grubu ve analiz edilmesi süreçleri hakkında açıklamalara yer verilmiştir.

Araştırma Modeli: Araştırmada betimsel yöntemlerden olan tarama modelinden faydalanılmıştır. Tarama modelinde amaç, seçilmiş olan örnekleme bağlı mevcut durumun olduğu şekliyle tespit edilmesidir (Karasar, 1994).

Evren-Örneklem: Araştırmanın evrenini 24-28 Nisan 2019 tarihinde Aydın ilinin Didim ilçesinde düzenlenen Gençler Türkiye Halter Şampiyonası'na katılan, halter sporcuları oluşturmaktadır. Örneklem grubunun belirlenmesinde kolayda örnekleme yönteminden yararlanılarak, 266 halter sporcusu araştırmaya katılım sağlamıştır.

Veri Toplama Araçları: Araştırma kapsamında "Demografik Bilgi Formu" ve "Etik Liderlik Ölçeği” veri toplama aracı olarak kullanılmıştır.

Demografik bilgi formu, katılımcıların antrenörleri hakkındaki demografik bilgileri elde etmek amacıyla kullanılmıştır. Toplamda 6 madde (cinsiyet, yaş, eğitim durumu, antrenörlük kademesi, milli sporcu ve görev yılı) içeren bu form, araştırmacılar tarafindan oluşturulmuştur.

Etik Liderlik Ölçeği (ELÖ), Yılmaz tarafından 2005 yılında geliştirilmiştir. Ölçek, 5'li likert tipinde olup 44 madde ve 4 alt boyuttan (İletişimsel Etik (.951), İklimsel Etik (.925), Karar Vermede Etik (.856) ve Davranışsal Etik (.949)) oluşmaktadır. Ölçeğin toplam güvenirlik katsayısı 0.978 bulunmuştur.

Araştırma Etiği: Bu çalışma, Bayburt Üniversitesi Etik Kurul Başkanlığının 15.05.2020 tarih ve 2020/31 kararı sayılı etik kurul iznine dayalı olarak yürütülmüştür.

Verilerin Analizi: Araştırma kapsamında elde edilen cevapların aritmetik ortalamaları ve standart sapmaları belirlenmiştir. Demografik bilgiler ile etik liderlik davranışları, parametrik testlerden One-Way ANOVA ve t-Testi kullanılarak sınanmıştır. Ayrıca anlamlı farklılaşmanın hangi gruplardan kaynaklandığının tespit edilmesi amacıyla, gruplara ait varyansların homojenliği dikkate alınarak Games-Howel ve Tukey testi kullanılmıştır. Araştırma grubunun yaş değişkeni ile Etik Liderlik Ölçeği alt boyutları arasındaki ilişkinin belirlenmesi amacıyla da Pearson Momentler Çarpımı Korelasyon (r) Katsayısı tekniğinden faydalanılmıştır. Yapılan analizler neticesinde anlamlılık düzeyi 0.05 olarak alınmıştır. 
Kul, M., Şipal, O., Aksoy, Ö.F. ve Boz, E. (2020). Sporcu algılarına göre halter antrenörlerinin etik liderlik davranıslarının incelenmesi. Spor Bilimleri Arastırmaları Dergisi, 5(2), 247-256.

\section{BULGULAR}

Araştırmanın bulgular bölümü, veri analizinin neticesinde elde edilmiş olan bulguların tablo yoluyla sunulmasını ve yorumlanmasını içermektedir.

Tablo 1. Cinsiyet, eğitim durumu, kademe, milli sporcu ve görev yıll değişkenlerine ilişkin yüzde ve frekanslar

\begin{tabular}{cccc}
\hline Değişken & Grup & f & \% \\
\hline \multirow{2}{*}{ Cinsiyet } & Erkek & 229 & 86,1 \\
& Kadın & 37 & 13,9 \\
Eğitim Durumu & İlkokul/Ortaokul/Lise & 84 & 31,6 \\
& Üniversite & 182 & 68,4 \\
& 1. Kademe & 32 & 12,0 \\
Antrenörlük & 2. Kademe & 66 & 24,8 \\
Kademesi & 3. Kademe & 79 & 29,7 \\
& 4. Kademe & 36 & 13,5 \\
& 5. Kademe & 53 & 19,9 \\
Milli Sporcu & Evet & 181 & 68,0 \\
& Hayır & 85 & 32,0 \\
Görev yllı & $1-5$ y1l & 69 & 25,9 \\
& 6-10 yıl & 87 & 32,7 \\
Toplam & 10 yll üzeri & 110 & 41,4 \\
& & 266 & 100,0 \\
\hline
\end{tabular}

Tablo 1'de araştırma grubuna ait kişisel bilgilere yer verilmiştir. Araştırma grubunun 229'unu $(\% 86,1)$ erkek, 37'sini $(\% 13,9)$ ise kadın katılımcılar oluşturmaktadır. Eğitim durumu değişkenine bağlı antrenörlerin 84'ü $(\% 31,6)$ ilkokul, ortaokul ve lise mezunu, 182'si $(\% 68,4)$ üniversite mezunudur. Antrenörlük kademesi değişkenine bağlı antrenörlerin 32'si $(\% 12,0)$ 1. Kademe, 66's1 $(\% 24,8)$ 2. Kademe, 79'u (\%29,7) 3. Kademe, 36’s1 (\%13,5) 4. Kademe ve 53'ü $(\% 19,9)$ 5. Kademe antrenörlük belgesine sahiptir. Milli sporcu geçmişi değişkenine bağlı antrenörlerin 181'i $(\% 68,0)$ milli sporcu iken, 85'i $(\% 32,0)$ milli sporcu değildir. Görev yılı değişkenine bağlı antrenörlerin 69'u (\%25,9) 1-5 y1l arası, 87'si $(\% 32,7)$ 6-10 yıl arası ve 110’u $(\% 41,4) 10$ y1l üzeri süre ile görev yapmaktadır ve toplamda 266 sporcu araştırmaya katılım sağlamıştır.

Tablo 2. Yaş değişkenine ilişkin tanımlayıcı istatistikler

\begin{tabular}{cccccc}
\hline Değişken & Ortalama & Medyan & Std. Sapma & Minimum & Maksimum \\
\hline Yaş & 37,000 & 35,000 & 10,6704 & 20,0 & 61,0 \\
\hline
\end{tabular}

Tablo 2 incelendiğinde, antrenörler için yaş değişkeninin ortalamasının 37, standart sapmasının ise 10,6704 olduğu görülmektedir.

Tablo 3. Etik liderlik ölçeği'ne ilişkin tanımlayıcı istatistikler

\begin{tabular}{lccccc}
\hline \multicolumn{1}{c}{ Alt Boyut } & Ortalama & Medyan & Std. Sapma & Çarpıklık & Basıklık \\
\hline İletişimsel Etik & 4.3857 & 4.6000 & .64160 & -.986 & .139 \\
İklimsel Etik & 4.3896 & 4.6364 & .63152 & -1.196 & 1.269 \\
Karar Vermede Etik & 4.2360 & 4.3333 & .65741 & -.518 & -.568 \\
Davranıssal Etik & 4.4160 & 4.6667 & .67080 & -1.185 & .909 \\
\hline
\end{tabular}

Tablo 3'te, Etik Liderlik Ölçeği'nin alt boyutlarına ilişkin tanımlayıcı istatistikler sunulmaktadır. $\mathrm{Bu}$ bağlamda çarpıklık ve basıklık değerleri incelendiğinde, veri setinin normal dağılım sergilediği kabul edilmiştir (Tabachnick ve Fidell, 2013). 
Kul, M., Şipal, O., Aksoy, Ö.F. ve Boz, E. (2020). Sporcu algılarına göre halter antrenörlerinin etik liderlik davranışlarının incelenmesi. Spor Bilimleri Araştırmaları Dergisi, 5(2), 247-256.

Tablo 4. Cinsiyet değişkenine iliş̧kin T-testi sonuçları

\begin{tabular}{ccccccc}
\hline Alt Boyut & Grup & N & Ortalaması & S. & t & p \\
\hline \multirow{2}{*}{ İletişimsel Etik } & Erkek & 229 & 4.3712 & \multirow{2}{*}{264} & -.919 & .359 \\
& Kadın & 37 & 4.4757 & & & \\
\multirow{2}{*}{ İklimsel Etik } & Erkek & 229 & 4.3831 & 264 & -.418 & .676 \\
& Kadın & 37 & 4.4300 & & & \\
\multirow{2}{*}{ Karar Vermede Etik } & Erkek & 229 & 4.2188 & 264 & -1.061 & .290 \\
& Kadın & 37 & 4.3423 & & & \\
Davranışsal Etik & Erkek & 229 & 4.4090 & 264 & -.424 & .672 \\
& Kadın & 37 & 4.4595 & & & \\
\hline
\end{tabular}

Tablo 4'e göre cinsiyet değişkenine ilişkin Etik Liderlik Ölçeğinin alt boyutlarından elde edilen verilerde anlamlı farklılığa rastlanmamıştır $(\mathrm{p}>0,05)$.

Tablo 5. Yaş değişkenine ilişkin pearson korelasyon analizi sonuçları

\begin{tabular}{lccccc}
\hline Değişken & & İletişimsel Etik & İklimsel Etik & Karar Vermede Etik & Davranışsal Etik \\
\hline \multirow{3}{*}{ Yaş } & $\mathrm{r}$ & -.086 & $-.114^{*}$ & $-.118^{*}$ & -.080 \\
& $\mathrm{p}$ & .082 & .032 & .027 & .096 \\
& $\mathrm{n}$ & 266 & 266 & 266 & 266 \\
\hline
\end{tabular}

Tablo 5'e göre yaş değişkeni ile Etik Liderlik Ölçeğinin “İletişimsel Etik” ve "Davranışsal Etik" alt boyutları arasında anlamlı ilişkiye rastlanmamıştır ( $p>0,05)$. Ancak "İklimsel Etik" ve "Karar Vermede Etik" alt boyutlarında düşük düzeyde negatif yönde anlamlı bir ilişki olduğu tespit edilmiştir $(\mathrm{p}<0,05)$. Bu sonuca göre, yaş artışına bağlı olarak "İklimsel Etik" ve "Karar Vermede Etik" alt boyutlarında azalma olduğu görülmektedir.

Tablo 6. Eğitim durumu değişkenine ilişkin T-testi sonuçları

\begin{tabular}{clccccc}
\hline Alt Boyut & Grup & N & Ortalaması & S. & t & p \\
\hline \multirow{2}{*}{ İletişimsel Etik } & İlkokul/Ortaokul/Lise & 84 & 4.3444 & 264 & -.712 & .477 \\
& Üniversite & 182 & 4.4048 & & & \\
\multirow{2}{*}{ İklimsel Etik } & İlkokul/Ortaokul/Lise & 84 & 4.3387 & 264 & -.892 & .373 \\
& Üniversite & 182 & 4.4131 & & & \\
Karar Vermede & İlkokul/Ortaokul/Lise & 84 & 4.2394 & 264 & .057 & .954 \\
Etik & Üniversite & 182 & 4.2344 & & & \\
Davranıssal Etik & İlkokul/Ortaokul/Lise & 84 & 4.3558 & \multirow{2}{*}{264} & -.995 & .321 \\
& Üniversite & 182 & 4.4438 & & & \\
\hline
\end{tabular}

Tablo 6'ya göre eğitim durumu değişkenine ilişkin Etik Liderlik Ölçeğinin alt boyutlarından elde edilen verilerde anlamlı farklılığa rastlanmamıştır $(\mathrm{p}>0,05)$. 
Kul, M., Şipal, O., Aksoy, Ö.F. ve Boz, E. (2020). Sporcu algılarına göre halter antrenörlerinin etik liderlik davranışlarının incelenmesi. Spor Bilimleri Araştırmaları Dergisi, 5(2), 247-256.

Tablo 7. Antrenörlük kademesi değişkenine ilişkin ANOVA sonuçları

\begin{tabular}{|c|c|c|c|c|c|c|c|}
\hline Alt Boyut & $\begin{array}{l}\text { Varyansın } \\
\text { Kaynağı }\end{array}$ & $\begin{array}{c}\text { Kareler } \\
\text { Toplamı }\end{array}$ & S. & $\begin{array}{c}\text { Kareler } \\
\text { Ortalaması }\end{array}$ & $\mathbf{F}$ & $\mathbf{p}$ & Anlamlı Fark \\
\hline \multirow{4}{*}{$\begin{array}{c}\text { İletişimsel } \\
\text { Etik }\end{array}$} & Gruplar Arası & 7.592 & 4 & 1.898 & & & \\
\hline & Gruplar İçi & 101.496 & 261 & .389 & 4.881 & .001 & $1>2,4,5$ ve \\
\hline & Toplam & 109.088 & 265 & & & & \\
\hline & Gruplar Arası & 4.952 & 4 & 1.238 & & & \\
\hline \multirow[t]{2}{*}{ İklimsel Etik } & Gruplar İçi & 100.736 & 261 & .386 & 3.208 & .014 & $1>2,5$ \\
\hline & Toplam & 105.688 & 265 & & & & \\
\hline \multirow{3}{*}{$\begin{array}{c}\text { Karar } \\
\text { Vermede } \\
\text { Etik }\end{array}$} & Gruplar Arası & 10,038 & 4 & 2,509 & & & \\
\hline & Gruplar İçi & 187,592 & 261 & ,719 & 3,491 &, 008 & $3>5$ \\
\hline & Toplam & 197,629 & 265 & & & & \\
\hline \multirow{3}{*}{$\begin{array}{c}\text { Davranısssal } \\
\text { Etik }\end{array}$} & Gruplar Arası & 5.811 & 4 & 1.453 & & & \\
\hline & Gruplar İçi & 113.431 & 261 & .435 & 3.343 & .011 & $1>5$ \\
\hline & Toplam & 119.242 & 265 & & & & \\
\hline
\end{tabular}

Tablo 7'ye göre antrenörlük kademesi değişkenine ilişkin “İletişimsel Etik” alt boyutunda 1. Kademe antrenörler ile 2, 4 ve 5. Kademe antrenörler arasında anlamlı farklılık olduğu tespit edilmiştir. "İklimsel Etik" alt boyutunda 1. Kademe antrenörler ile 2 ve 5. Kademe antrenörler arasında anlamlı farklılık olduğu tespit edilmiştir. "Karar Vermede Etik" alt boyutunda 3. Kademe antrenörler ile 5. Kademe antrenörler arasında anlamlı farklılık olduğu tespit edilmiştir. "Davranışsal Etik" alt boyutunda 1. Kademe antrenörler ile 5. Kademe antrenörler arasında anlamlı farklılık olduğu sonucuna ulaşılmıştır $(\mathrm{p}<0,05)$.

Tablo 8. Milli sporcu değişkenine ilişkin T-testi sonuçları

\begin{tabular}{ccccccc}
\hline Alt Boyut & Grup & $\mathbf{N}$ & Ort. & S. & t & p \\
\hline \multirow{2}{*}{ İletişimsel Etik } & Evet & 181 & 4.4313 & \multirow{2}{*}{264} & \multirow{2}{*}{1.697} & .091 \\
& Hayır & 85 & 4.2886 & & & \\
İklimsel Etik & Evet & 181 & 4.4355 & 264 & 1.734 & .084 \\
Karar Vermede & Hayır & 85 & 4.2920 & & & \\
$\quad$ Etik & Evet & 181 & 4.2793 & 264 & 1.572 & .117 \\
Davranışsal & Hayır & 85 & 4.1438 & & & \\
Etik & Evet & 181 & 4.4696 & 264 & 1.910 & .057 \\
\hline
\end{tabular}

Tablo 8'e göre milli sporcu değişkenine ilişkin Etik Liderlik Ölçeğinin alt boyutlarından elde edilen verilerde anlamlı farklılığa rastlanmamıştır ( $\mathrm{p}>0,05)$.

Tablo 9. Görev yılı değişkenine ilişkin ANOVA sonuçları

\begin{tabular}{|c|c|c|c|c|c|c|c|}
\hline Alt Boyut & $\begin{array}{l}\text { Varyansın } \\
\text { Kaynağı }\end{array}$ & $\begin{array}{l}\text { Kareler } \\
\text { Toplamı }\end{array}$ & S. & $\begin{array}{c}\text { Kareler } \\
\text { Ortalaması }\end{array}$ & $\mathbf{F}$ & $\mathbf{p}$ & $\begin{array}{l}\text { Anlamlı } \\
\text { Fark }\end{array}$ \\
\hline \multirow{3}{*}{ İletişimsel Etik } & Gruplar Aras1 & 1.865 & 2 & .932 & & & \\
\hline & Gruplar İçi & 107.223 & 263 & .408 & 2.287 & .104 & --- \\
\hline & Toplam & 109.088 & 265 & & & & \\
\hline \multirow{3}{*}{ İklimsel Etik } & Gruplar Aras1 & 1.862 & 2 & .931 & & & \\
\hline & Gruplar İçi & 103.826 & 263 & .395 & 2.358 & .097 & --- \\
\hline & Toplam & 105.688 & 265 & & & & \\
\hline \multirow{3}{*}{$\begin{array}{c}\text { Karar } \\
\text { Vermede Etik }\end{array}$} & Gruplar Aras1 & 2.636 & 2 & 1.318 & & & \\
\hline & Gruplar İçi & 111.893 & 263 & .425 & 3.098 & .047 & $\begin{array}{l}\text { 0-10 yil > 10 } \\
\text { vil üzeri }\end{array}$ \\
\hline & Toplam & 114.530 & 265 & & & & \\
\hline \multirow{3}{*}{$\begin{array}{c}\text { Davranısssal } \\
\text { Etik }\end{array}$} & Gruplar Aras1 & 1.371 & 2 & .686 & & & \\
\hline & Gruplar İçi & 117.871 & 263 & . 448 & 1.530 & .218 & --- \\
\hline & Toplam & 119.242 & 265 & & & & \\
\hline
\end{tabular}


Kul, M., Şipal, O., Aksoy, Ö.F. ve Boz, E. (2020). Sporcu algılarına göre halter antrenörlerinin etik liderlik davranışlarının incelenmesi. Spor Bilimleri Araştırmaları Dergisi, 5(2), 247-256.

Tablo 9'a göre görev yılı değişkenine ilişkin “İletişimsel Etik”, “İklimsel Etik” ve "Davranışsal Etik" alt boyutlarından elde edilen verilerde anlamlı farklılığa rastlanmamıştır (p>0,05). "Karar Vermede Etik" alt boyutunda ise 6-10 y1l arası görev yapan antrenörler ile 10 yıl üzeri görev yapan antrenörler arasında anlamlı farklılık olduğu tespit edilmiştir $(\mathrm{p}<0,05)$.

\section{TARTIŞMA VE SONUÇ}

Araştırma sonuçları doğrultusunda, cinsiyet değişkeniyle etik liderlik ölçeğinin alt boyutları arasında anlamlı farklılık bulunmamıştır. Eratlı Şirin, Karaşoğlu, Aydın ve Gönen Yıldız'ın (2019) hem eğitimci hem de lider olarak nitelendirdikleri öğretim elemanları ile gerçekleştirdikleri araştırma sonuçları da benzer şekilde cinsiyet değişkeninin etik liderlik davranışlarını etkilemediği yönündedir. Poohongthong, Surat ve Sutipan'ın (2014) araştırma grubunu öğretmenlerin oluşturduğu çalışmalarının sonucu da cinsiyet değişkeninin etik liderlik davranışlarında belirleyici bir unsur olmadığı yönündedir. Bu verilere dayanarak etik değerlerin evrensel olduğu ve cinsiyet değişkeni ile ayrıştırılamayacağı söylenebilir.

Yaş değişkenine bağlı ölçeğin "İletişimsel Etik" ile "Davranışsal Etik" alt boyutları arasında anlamlı ilişkiye rastlanmamıştır. Ancak "İklimsel Etik" ve "Karar Vermede Etik" alt boyutlarında düşük düzeyli negatif yönlü anlamlı bir ilişkinin olduğu bulunmuştur. Ayten (2019), araştırmasında okul sporlarında antrenörlük yapan beden eğitimi ve spor öğretmenleriyle çalışmış ve araştırma sonuçlarına göre 41-50 yaş aralığındaki katılımcıların sergiledikleri liderlik davranışları diğer yaş gruplarına göre daha yüksek düzeydedir. İnanlı'nın (2019) masa tenisi antrenörlerinin örneklem grubunu oluşturduğu araştırmasında 26-29 yaş aralığında demokratik liderlik özelliğinin yoğun olarak görüldüğünü belirtilmiştir. Korkmazer, Pirol ve Güneysu (2020) ise yaş değişkenin artışı ile etik liderlik davranışının daha az sergilendiği sonuçlarına ulaşmışlardır. Chelladurai ve Saleh'nin (1978) "Çok Boyutlu Liderlik Modeli” de verilerimizi destekler nitelikte, bir liderin özellikleri arasında biyolojik yaşın etkili bir unsur olduğunu ve bireysel farklılıklara bağlı olarak değişkenlik gösterebileceğini de ifade etmektedir. Bu bağlamda halter antrenörlerinin yaş değişkenlerinin, bireysel farklılıklara bağlı olarak liderlik özelliklerini etkilediği söylenebilir.

Eğitim durumu değişkenine ilişkin Etik Liderlik Ölçeğinin alt boyutlarından elde edilen verilerde anlamlı farklılığa rastlanmamıştır. Paydaş (2019) araştırma sonucumuzla örtüşen bir veri elde ederek farklı spor branşlarından antrenörlerin örneklem grubunu oluşturduğu çalışmasında eğitim durumunun liderlik tarzını etkileyen bir değişken olmadığını belirtmiştir. Burton, Peachey ve Wells (2017) ise antrenörlerin etik liderlik davranışları sergilemelerinin temelinde etik değerleri benimsenin yer aldığını ve ekip içerisindeki güven duygusuyla ilişkili olduğu sonucuna ulaşmışlardır. Bu sonuçlar da liderliğin herhangi bir eğitim programına bağlı olmaksızın kişisel bir özellik olduğu sonucunu desteklemektedir.

Katılımcıların antrenörlük kademesi değişkenine ilişskin Etik Liderlik Ölçeğinin tüm alt boyutlarında anlamlı farklılık tespit edilmiştir. Bu veriyi destekler nitelikte, Çetintaş'ın (2019) karate antrenörleri ile gerçekleştirdiği araştırmasında da tüm alt boyutlarda anlamlı farklılığa ulaşılmıştır. Bu sonuçlar ağırlıklı olarak 1. Kademe ve 5. Kademe antrenörler arasındaki farklılaşmadan kaynaklanmaktadır. Milli sporcu olma değişkenine ilişkin Etik Liderlik Ölçeğinin alt boyutlarından elde edilen verilerde anlamlı farklılığa rastlanmamıştır. 
Görev y1lı değişkenine ilişkin "İletişimsel Etik", “İklimsel Etik” ve "Davranışsal Etik” alt boyutlarından elde edilen verilerde anlamlı farklılığa rastlanmamıştır. "Karar Vermede Etik" alt boyutunda ise 6-10 yıl arasında görevli antrenörler ile 10 yıl üzeri görev yapan antrenörler arasında anlamlı fark olduğu bulunmuştur. Özalp (2019) futbol antrenörlerinin görev yılı değişkenine bağlı olarak "Otoriter Davranış" alt boyutunda farklılaşma tespit ederken, Bayırdır (2018) "Demokratik Davranış", "Otoriter Davranış" ve "Sosyal Destek" alt boyutlarında anlamlı farklılık tespit etmiştir. Constandt, De Waegeneer ve Willem'in (2018) araştırma sonuçları ise profesyonel antrenörlerin daha fazla etik liderlik davranışı sergilediği, takım içerisinde etik iklimin oluştuğu ve örgütsel bağlılığın arttığı yönündedir. Antrenörlük kademesi, milli sporcu olma durumu ve antrenörlük mesleğindeki görev süresi tecrübe ile ilişkili değişkenler olmakla birlikte liderlik tarzları olaylara ve içerisinde bulunulan durumlara göre farklı sonuçlar verebilmektedir. Bu bağlamda mesleki tecrübe gerektiren durumların antrenörler üzerinde etkili olmasıyla birlikte etik algılarına ve liderlik tarzlarını etkileyebileceği söylenebilir.

Elde edilen bulgular ışığında, liderlik özellikleri bakımından halter antrenörlerinin; yaşları arttıkça iklimsel ve karar vermede etik değerleri daha az sergiledikleri, antrenörlük kademeleri arttıkça iletişimsel, iklimsel, davranışsal ve karar vermede etikten uzaklaştıkları, görev süreleri arttıkça mesleki deformasyon kaynaklı, karar vermede etik kurallara daha az yer verdikleri düşünülmektedir.

Çıkar Çatışması: Yazarlar arasında herhangi bir çıkar çatışması bulunmamaktadır.

Yayın Etiği: Mevcut çalışmanın yazım sürecinde "Yükseköğretim Kurumları Bilimsel Araştırma ve Yayın Etiği Yönergesi” kapsamında bilimsel, etik ve alıntı kurallarına uyulmuş olup; toplanan veriler üzerinde herhangi bir tahrifat yapılmamış ve bu çalışma herhangi başka bir akademik yayın ortamına değerlendirme için gönderilmemiştir. 
Kul, M., Şipal, O., Aksoy, Ö.F. ve Boz, E. (2020). Sporcu algılarına göre halter antrenörlerinin etik liderlik davranışlarının incelenmesi. Spor Bilimleri Araştırmaları Dergisi, 5(2), 247-256.

\section{KAYNAKLAR}

Argüden, Y. (2016). Kamuda iyi yönetişim. İstanbul: Argüden Yönetişim Akademisi Yayınları.

Ayten, İ. (2019). Okul sporlarında antrenör olarak yer alan beden eğitimi ve spor öğretmenlerinin liderlik algıları ile liderlik özellikleri arasındaki ilişkinin incelenmesi. Yüksek Lisans Tezi, Batman Üniversitesi, Sosyal Bilimler Enstitüsü, Rekreasyon yönetimi Anabilim Dalı, Batman.

Bayındır, M. (2019). Antrenörlerin liderlik özellikleri ile empati düzeyleri arasındaki ilişkinin incelenmesi. Yüksek Lisans Tezi, Akdeniz Üniversitesi, Sosyal Bilimler Enstitüsü, Spor Yöneticiliği Anabilim Dalı, Antalya.

Burton, L. J., Peachey, J. W. \& Wells, J. E. (2017). The role of servant leadership in developing an ethical climate in sport organizations. Journal of Sport Management, 31(3), 229-240. https://doi.org/10.1123/jsm.2016-0047.

Chelladurai, P. \& Saleh, S. D. (1978). Preferred leadership in sports. Canadian Journal of Applied Sport Sciences, 3, 85-92.

Constandt, B., De Waegeneer, E. \& Willem, A. (2018). Coach ethical leadership in soccer clubs: an analysis of its influence on ethical behavior. Journal of Sport Management, 32(3), 185-198. https://doi.org/10.1123/jsm.2016-0047.

Çetintaş, Y. (2019). Karate antrenörlerinin liderlik yönelimlerinin incelenmesi. Yüksek Lisans Tezi, Bartın Üniversitesi, Eğitim Bilimleri Enstitüsü, Beden Eğitimi ve Spor Bilimleri Anabilim Dalı, Bartın.

Elahe, B., Dehnavi, A., Mansouri, M. \& Nami, A. (2013). The relationship between leadership styles and coaching emotional intelligence in selected individual sports of universities of Tehran. European Journal of Experimental Biology, 3(2), 48-53.

Eratlı Şirin, Y., Karaşoğlu, G., Aydın, Ö. ve Gönen Yıldız, S. (2019). Etik liderlik ve toplumsal cinsiyet: Üniversite ögretim elemanları üzerine bir araştırma. S. Patlar (Ed.), 17. Uluslararası Spor Bilimleri Kongresi tam metin kitabı içinde (ss. 2886-2894). Antalya.

Gulak Lipka, P. (2016). The role of trust for leadership in team sports. Journal of Corporate Responsibility and Leadership, 3(3), 39-47. https://doi.org/10.12775/JCRL.2016.015.

Güçlü, N. ve Koşar, S. (2018). Eğitim yönetiminde liderlik teori, araştırma ve uygulama. Ankara: Salmat Basım Yayıncilik.

International Coaches Federation (2003). ICF Standart of Ethical Conduct. [Available online at: http://www.1cfoffice@coachfederation.org.], Erişim tarihi: 05 Mart 2020.

İnanl1, Y. (2019). Doğu anadolu bölgesindeki masa tenisi antrenörlerinin liderlik tarzlarının incelenmesi. Yüksek Lisans Tezi, Ağrı İbrahim Çeçen Üniversitesi, Sağlık Bilimleri Enstitüsü, Beden Eğitimi ve Spor Anabilim Dalı, Ağrı.

Korkmazer, F., Pirol, M. ve Güneysu, E. (2020). Hemşirelerin hastane etik iklim algılarının performansları üzerine etkisi. Anemon Muş Alparslan Üniversitesi Sosyal Bilimler Dergisi, 8(1), 163-170. https://doi.org/10.18506/anemon.523438.

Meier, J. F. \& Henderson, K. A. (2016). Camp counseling, Çeviri: Günay G. Kamp Liderliği. Ankara: GSB Eğitim ve Kültür Araştırma Genel Müdürlüğü Yayınları. 
Kul, M., Şipal, O., Aksoy, Ö.F. ve Boz, E. (2020). Sporcu algılarına göre halter antrenörlerinin etik liderlik davranışlarının incelenmesi. Spor Bilimleri Araştırmaları Dergisi, 5(2), 247-256.

Özalp, A. (2019). Futbol antrenörlüğü yapan bireylerin liderlik tarzlarının belirlenmesi (Balıkesir il örneği). Yüksek Lisans Tezi, Balıkesir Üniversitesi, Sağlık Bilimleri Enstitüsü, Beden Eğitimi ve Spor Anabilim Dalı, Balıkesir.

Paydaş, M. (2019). Antrenörlerin liderlik tarzlarının problem çözme becerisine olan etkisi. Yüksek Lisans Tezi, Karamanoğlu Mehmetbey Üniversitesi, Sosyal Bilimler Enstitüsü, Beden Eğitimi ve Spor Anabilim Dalı, Karaman.

Poohongthong, C., Surat, P. \& Sutipan, P. (2014). A Study on the relationships between ethical leadership, work-life balance, organizational socialization, and organizational citizenship behavior of teachers in Northern Thailand. The Journal of Behavioral Science, 9(2), 17-28. https://doi.org/10.14456/ijbs.2014.2.

Sunay, H. (2016). Spor yönetimi. Ankara: Gazi Kitabevi.

Tabachnick, B. G. \& Fidell, L. S. (2013). Using multivariate statistics. Boston: Pearson.

Taylor, F. W. (2018). The principle of scientific managenent. Çeviri: Akın HB. Bilimsel Yönetimin Illkeleri. Konya: Çimke Basımevi.

Yaman, A. (2010). İç denetçinin yeni rolü: Etik liderlik. Denetişim, (5), 9-16. [Available online at: https://dergipark.org.tr/tr/pub/denetisim/issue/22480/240464].

Yeşilyurt, P. (2007). Türk ve İtalyan yöneticilerin liderlik tarzlarl: Türkiye'de faaliyet gösteren Türk-Ittalyan ortak girişimlerinde bir uygulama. Yüksek Lisans Tezi, Çukurova Üniversitesi, Sosyal Bilimler Enstitüsü, İşletme Anabilim Dalı, Adana.

Yılmaz, E. (2005). Etik liderlik ölçeği’nin geçerlik ve güvenirlik çalışması. H. Kıran (Ed.), XIV.Eğitim Bilimleri Kongresi bildiriler kitabı içinde (ss. 808-814). Denizli: Pamukkale Üniversitesi.

Bu eser Creative Commons Atıf-GayriTicari 4.0 Uluslararası Lisansı ile lisanslanmıştır 